\title{
Synthesis and Characterization of Heparin-Doped Polypyrrole Coatings Using an Electrochemical Quartz Crystal Microbalance (EQCM)
}

\author{
D. O. Flamini ${ }^{1,2,}$, M. B. González ${ }^{1,2}$ and S. B. Saidman ${ }^{1,2}$ \\ ${ }^{1}$ Institute of Chemical Engineering and Corrosion (INIEC), Chemical Engineering \\ Department, National University of the South, Bahia Blanca, Argentina \\ ${ }^{2}$ National Scientific and Technical Research Council (CONICET), Bahía Blanca, Argentina \\ *Corresponding author: dflamini@uns.edu.ar
}

Received 03/04/2019; accepted 10/05/2021

https://doi.org/10.4152/pea.2022400104

\begin{abstract}
Polypyrrole (PPy) films were electrochemically synthesized on an $\mathrm{Au} / \mathrm{TiO}_{2}$ coated quartz crystal electrode in solutions with different heparin (Hep) concentrations. The PPy films morphology was determined by tapping a mode atomic force microscopy (AFM). The influence of the dopant concentration on the coating surface roughness was studied. Electrochemical quartz crystal microbalance (EQCM) results suggest that Hep retained in the PPy films was bound to thrombin. The adsorbed thrombin amount increased with a higher coating surface roughness. PPy films doped with Hep are electroactive and show cation exchange properties under oxidation or reduction conditions in a Ringer solution. The pre-oxidized PPy film adsorbed a greater thrombin amount than the freshly one and even more than the pre-reduced film.
\end{abstract}

Keywords: EQCM, Polypyrrole, Heparin and Thrombin.

\section{Introduction}

It is known that heparin (Hep) is a linear polysaccharide that has antithrombogenic properties [1]. Hep is a heterogeneous polymer of uronic acid and D-glucosamine substituted by $\mathrm{N}$-sulfate and $\mathrm{O}$-sulfate groups [2], of which general structure is shown below:

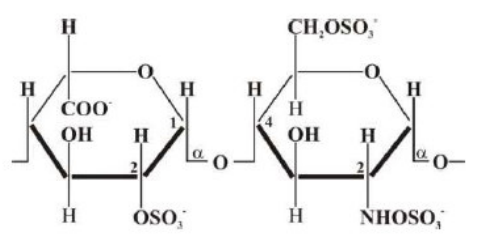

On the other hand, polypyrrole (PPy) is a material biocompatible with the human body tissues and it is used as an organic coating for a great number of biomedical applications $[3,4]$. The principles from the cation and anion-exchanges, in the composite PPy films doped with different bulky anions (quinones) amounts during pyrrole electropolimerization, were characterized by the electrochemical quartz crystal microbalance (EQCM) technique. The obtained results demonstrated the 
possibility to control the composition of the prepared films and evaluate their relative doping level [5]. The pioneer study of ion dynamics in Hep-doped PPy films using the EQCM technique showed that the charge on Hep trapped in a PPy matrix changes with the $\mathrm{pH}$ solution. At a neutral $\mathrm{pH}$, the PPy/Hep film functions as a cation-exchange membrane. In very acidic solutions, the PPy/Hep film functions as an anion-exchange membrane [6]. The electrochemical synthesis of PPy coatings onto a Nitinol (NiTi) alloy using different Hep concentrations has been carried out successfully in our laboratory [7]. The pyrrole (Py) monomer was oxidized anodically onto the alloy surface to produce PPy films, and Hep was incorporated into the polymeric matrix as an anionic dopant, in order to assure its electrical neutrality. Furthermore, the PPy film anticoagulant ability in blood plasma was determined. The incorporation of bioactive molecules, such as Hep, into the polymer matrix improves its biocompatibility with the human body, as proposed by Cornelius et al. [8]. Zhou et al. [9] studied the Hep incorporation as a polyelectrolyte during PPy electropolymerization, and evaluated the polymeric coating electrochemical properties by using EQCM. They also determined the type of interaction existing between the Hep-doped PPy coating and different kinds of test proteins, with respect to thrombin. The influence exerted on the thrombin adsorption employing different Hep concentrations, during the PPy electrosynthesis, was not studied by EQCM. In this sense, the PPy electrochemical polymerization was carried out in the EQCM cell using different Hep concentrations. The polymer dopant concentration and oxidation state effects on the thrombin adsorption process were analyzed.

\section{Material and methods}

The electrochemical measurements were carried out using an Autolab/PGSTAT128N potentiostat-galvanostat (from Metrohm-Autolab B.V.), equipped with an EQCM module. AT-cut quartz crystals with a small temperature coefficient $\left(0.6 \mathrm{~Hz} \mathrm{~K}^{-1}\right)$ were used.

The typical three-electrode arrangement was employed as an electrochemical cell with a maximum volume of $3 \mathrm{~mL}$. The working electrode was covered with $\mathrm{Au}$ on top of a $\mathrm{TiO}_{2}\left(\mathrm{Au} / \mathrm{TiO}_{2}\right)$ adhesion layer, with an active surface of $0.361 \mathrm{~cm}^{2}$. The reference and the counter electrodes were an $\mathrm{Ag} / \mathrm{AgCl} / \mathrm{KCl}$ (sat) electrode and a gold spirally shaped wire, respectively. The reference electrode was of the lowleakage type, so no significant solution contamination was expected. All potentials in the text are referred to the $\mathrm{Ag} / \mathrm{AgCl} / \mathrm{KCl}$ (sat) electrode ( $0.197 \mathrm{~V}$ vs. $\mathrm{NHE}$ ).

The change on the oscillation frequency $(\Delta \mathrm{f})$ is sensitive to the change in mass deposited on the crystal surface $(\Delta \mathrm{m})$, meaning that any variation in the electrode mass or in the deposited material thickness will proportionally change the crystal oscillation frequency. The relationship between $\Delta \mathrm{f}$ and $\Delta \mathrm{m}$ is given by the "Sauerbrey equation" [10]:

$$
\begin{gathered}
\Delta f=-C_{f} \cdot \Delta m \\
C_{f}=\frac{2 n \cdot f^{2}}{\sqrt{\rho_{q} \cdot \mu_{q}}}
\end{gathered}
$$


where $\Delta \mathrm{f}$ is the change in frequency $(\mathrm{Hz}), \mathrm{C}_{\mathrm{f}}$ is the crystal sensitivity factor $\left(0.0815 \mathrm{~Hz} \mathrm{ng}^{-1} \mathrm{~cm}^{2}\right.$, at $\left.20^{\circ} \mathrm{C}\right), \Delta \mathrm{m}$ is the change in mass per unit area $\left(\mathrm{g} \mathrm{cm}^{-2}\right), \mathrm{n}$ is the number of harmonic at which the crystal is driven $(\mathrm{n}=1), \mathrm{f}$ is the resonant frequency of the loaded crystal fundamental mode $(\mathrm{Hz}), \rho_{\mathrm{q}}$ is the quartz density $\left(2.648 \mathrm{~g} \mathrm{~cm}^{-3}\right)$ and $\mu_{\mathrm{q}}$ is the quartz shear modulus $\left(2.947 \times 10^{11} \mathrm{~g} \mathrm{~cm}^{-1} \mathrm{~s}^{-2}\right)$. From equations (1) and (2), the change in mass can be calculated as follows:

$$
\Delta m=\frac{-\Delta f}{C_{f}}=\frac{\left(f_{q}-f\right) \sqrt{\rho_{q} \mu_{q}}}{2 n \cdot f^{2}}
$$

where $f_{q}$ is the fundamental mode of the downloaded crystal resonant frequency (Hz). In this case, the AT-crystal nominal frequency is $6 \mathrm{MHz}$.

PPy films were electrochemically deposited on an $\mathrm{Au} / \mathrm{TiO}{ }_{2}$ coated quartz crystal electrode from a solution with $0.50 \mathrm{M}$ Py and different Hep concentrations (0.20, 0.30 and $\left.0.40 \mathrm{~g} \mathrm{~L}^{-1}\right)$. The EQCM cell was filled with $2 \mathrm{~mL}$ of these solutions. Electrochemical polymerization was carried out under potentiodynamic and galvanostatic conditions. For simplification, the films synthesized under galvanostatic control will be named as $\mathrm{PP}_{\mathrm{xH}}$, where $\mathrm{x}$ represents the Hep concentration in $\mathrm{g} \mathrm{L}^{-1}$ in the solution.

All chemicals were reagent grade, and the solutions were prepared using triply distilled water. Py (Sigma-Aldrich) was freshly distilled under reduced pressure before use. Heparin sodium salt from porcine intestinal mucosa (Grade I-A, with an activity of 180 USP units $\mathrm{mg}^{-1}$ and molecular weight from 17000 to $19000 \mathrm{Da}$ ), was purchased from Sigma-Aldrich and used as-received.

All PPy $y_{x H e p}$ films coated quartz electrodes were washed with triply distilled water before any further experimentation.

Thrombin adsorption onto $\mathrm{PP}_{\mathrm{x} H e p}$ films coated quartz electrodes was investigated using EQCM. The cell was filled with $2 \mathrm{~mL}$ of a Ringer solution $\left(0.147 \mathrm{M} \mathrm{NaCl}, 0.00432 \mathrm{M} \mathrm{CaCl}_{2}\right.$ and $\left.0.00404 \mathrm{M} \mathrm{KCl}\right)$, which is frequently used to simulate a biological environment. Frequencies, corresponding to the quartz crystal mass change, were registered, before and after adding another $1 \mathrm{~mL}$ of the Ringer solution with $25 \mathrm{NIH}$ units or $20.15 \mu \mathrm{g}$ of thrombin, under open circuit potential (OCP) conditions. Brukenstein et al. have demonstrated that the change in the cell solution volume has not affected the reading frequency [11].

The PPy films morphology was characterized at room temperature, by an atomic force microscope (AFM) (Innova, Bruker) operated in tapping mode, using uncoated Si tips with a cantilever length of $125 \mu \mathrm{m}$, spring constant of $40 \mathrm{Nm}^{-1}$ and resonant frequency from 60 to $90 \mathrm{kHz}$, purchased from NanoWorld. All images were taken at $512 \times 512$ pixel resolution, with a scan size of $2 \mu \mathrm{m} \times 2 \mu \mathrm{m}$.

\section{Results and discussion}

\section{Electrochemical synthesis of PPy films in the EQCM cell and AFM studies}

The electrochemical synthesis of PPy films on an $\mathrm{Au} / \mathrm{TiO}_{2}$ coated quartz crystal electrode was made in solutions with the $0.50 \mathrm{M}$ Py monomer and different Hep concentrations $\left(0.20,0.30\right.$ and $\left.0.40 \mathrm{~g} \mathrm{~L}^{-1}\right)$. In order to address the electrochemical behavior during the synthesis, cyclic voltammetry $(\mathrm{CV})$ was carried out from -1.20 to $1.50 \mathrm{~V}(\mathrm{Ag} / \mathrm{AgCl} / \mathrm{KCl}(\mathrm{sat}))$, at a scan rate of $0.05 \mathrm{~V} \mathrm{~s}^{-1}$ (Fig. 1). 

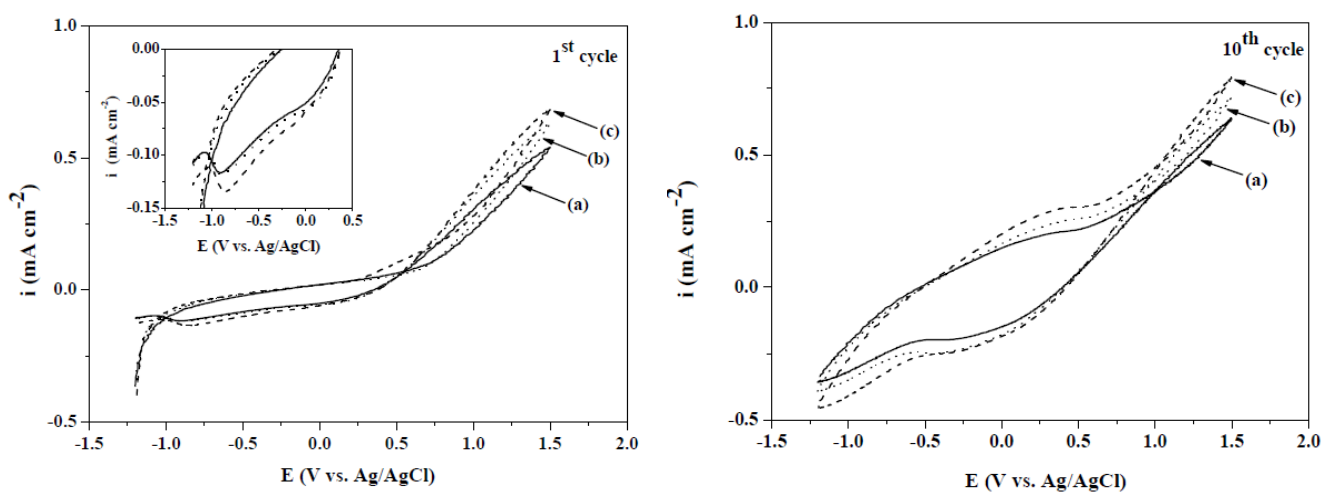

Figure 1. $\mathrm{CV}$ obtained for an $\mathrm{Au} / \mathrm{TiO}_{2}$ coated quartz crystal electrode in a $0.50 \mathrm{M}$ Py solution with different Hep concentrations: (a) 0.20 , (b) 0.30 and (c) $0.40 \mathrm{~g} \mathrm{~L}^{-1}$. The first and tenth cycles are displayed. Scan rate: $0.05 \mathrm{~V} \mathrm{~s}^{-1}$. In the case of the first cycle, the $\mathrm{CV}$ cathodic region is shown magnified.

According to the first cycle observed in Fig. 1, the anodic process related to the Py oxidation beginning is produced at around $0.75 \mathrm{~V}(\mathrm{Ag} / \mathrm{AgCl} / \mathrm{KCl}(\mathrm{sat}))$. When the Hep concentration is increased, the Py oxidation potential is shifted to more negative values. As it can be observed in the tenth cycle of Fig. 1, repetitive cycling results in a progressive increase in the charge of the redox waves appearing at a more negative potential than that corresponding to the monomer oxidation. A black and uniform PPy layer covering the entire substrate was observed after cycling, indicating that these redox waves are associated with polymeric deposits. Two reduction peaks were observed (insert of Fig. 1) in the negative potential scan of the first cycle. It has been previously demonstrated that Hep molecules are partially retained, considering their large volume [7, 9]. The first peak observed at $-0.10 \mathrm{~V}(\mathrm{Ag} / \mathrm{AgCl} / \mathrm{KCl}(\mathrm{sat}))$ could be attributed to the expulsion of a Hep polyanion fraction. The second one was located at around $-0.80 \mathrm{~V}(\mathrm{Ag} / \mathrm{AgCl} / \mathrm{KCl}(\mathrm{sat}))$, which could be related to the $\mathrm{Na}^{+}$ions insertion into the polymer, in order to maintain charge neutrality.

$\mathrm{PPy}_{\mathrm{xHep}}$ films electrochemical synthesis on $\mathrm{Au} / \mathrm{TiO}_{2}$ coated quartz crystal electrodes was also performed galvanostatically using a current density of $0.624 \mathrm{~mA} \mathrm{~cm}^{-2}$, during $300 \mathrm{~s}$. A typical E vs. t profile was obtained (Fig. 2), where the Py oxidation potential decreases as Hep concentration increases.

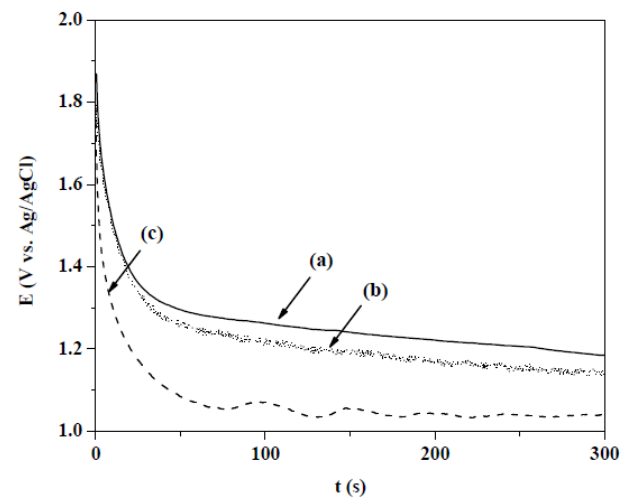

Figure 2. $E$ vs. $t$ transients obtained for an $\mathrm{Au} / \mathrm{TiO}_{2}$ coated quartz crystal electrode, at a current density of $0.624 \mathrm{~mA} \mathrm{~cm}{ }^{-2}$, during $300 \mathrm{~s}$, in a $0.50 \mathrm{M}$ Py solution with different Hep concentrations: (a) 0.20 , (b) 0.30 and (c) $0.40 \mathrm{~g} \mathrm{~L}^{-1}$. 
According to $\Delta$ f vs. t profile (Fig. 3) the PPy amount deposited on $\mathrm{Au} / \mathrm{TiO}_{2}$ coated quartz crystal electrodes increases as Hep concentration rises. $\Delta \mathrm{f}$ values are proportional to time for all employed Hep concentrations.

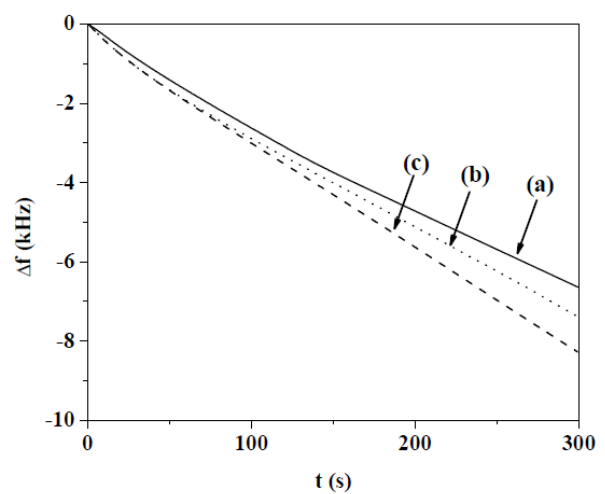

Figure 3. $\Delta f$ ss. $t$ response obtained for an $\mathrm{Au} / \mathrm{TiO}_{2}$ coated quartz crystal electrode, at a current density of $0.624 \mathrm{~mA} \mathrm{~cm}^{-2}$, during $300 \mathrm{~s}$, in a $0.50 \mathrm{M}$ Py solution with different Hep concentrations: (a) 0.20 , (b) 0.30 and (c) $0.40 \mathrm{~g} \mathrm{~L}^{-1}$.

Table 1. $\Delta f$ and $\Delta m$ values obtained for PPyxHep films formed at a current density of $0.624 \mathrm{~mA} \mathrm{~cm}^{-2}$, during $300 \mathrm{~s}$, in $0.50 \mathrm{M}$ Py solutions with different Hep concentrations $\left(0.20,0.30\right.$ and $\left.0.40 \mathrm{~g} \mathrm{~L}^{-1}\right)$.

\begin{tabular}{cccc}
\hline $\begin{array}{c}\text { Synthesis solution } \\
\left(\mathbf{0 . 5 0} \mathbf{M} \mathbf{P y}+\mathbf{x ~ g L}^{-\mathbf{1}} \mathbf{H e p}\right)\end{array}$ & $\begin{array}{c}-\Delta \boldsymbol{f} \\
(\mathbf{k H z})\end{array}$ & $\begin{array}{c}\Delta \boldsymbol{m} \\
(\boldsymbol{\mu g})\end{array}$ & $\begin{array}{c}\Delta \mathbf{m} / \mathbf{Q} \\
\left(\boldsymbol{\mu g} \mathbf{~ m C}^{-\mathbf{1}}\right)\end{array}$ \\
\hline 0.20 & 6.64 & 29.40 & 0.435 \\
0.30 & 7.38 & 32.70 & 0.484 \\
0.40 & 8.28 & 36.67 & 0.543 \\
\hline
\end{tabular}

$\mathrm{PP}_{0.20 \mathrm{Hep}}$ and $\mathrm{PP}_{0.40 \mathrm{Hep}}$ films were characterized by using AFM tapping mode (Fig. 4).

$\Delta \mathrm{f}$ and $\Delta \mathrm{m}$ values related to the PPy deposition are reported in Table 1 , after application of a current density of $0.624 \mathrm{~mA} \mathrm{~cm}^{-2}$, during $300 \mathrm{~s}$, for all Hep concentrations. Considering that the charge (Q) consumed after polymerization was $67.6 \mathrm{mC}$, Table 1 also reports the change in mass per unit of the polymerization charge $(\Delta \mathrm{m} / \mathrm{Q})$.
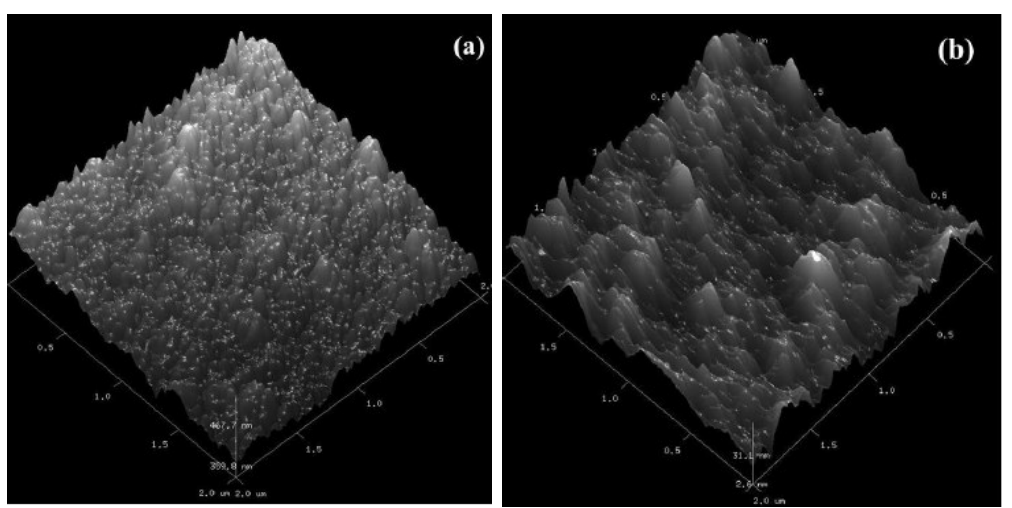

Figure 4. AFM tapping mode images obtained for: (a) $\mathrm{PP}_{0.20 \mathrm{Hep}}$ and (b) $\mathrm{PP}_{0.40 \mathrm{Hep}}$ films. PPy $0.20 \mathrm{Hep}$ and PPy $0.40 \mathrm{Hep}$ films were prepared at a current density of $0.624 \mathrm{~mA} \mathrm{~cm}{ }^{-2}$, during $300 \mathrm{~s}$, in a $0.50 \mathrm{M}$ Py solution with 0.20 and $0.40 \mathrm{~g} \mathrm{~L}^{-1}$ of Hep, respectively. 
The studies demonstrated that PРy0.20Hep (Fig. 4a) and PРy.40Hep (Fig. 4b) films have a dendritic porous morphology, with a roughness of 118 and $58.2 \mathrm{~nm}$, respectively. It was also previously observed that the Hep-doped PPy coating obtained on NiTi under potentiostatic control has the typical granular morphology of this polymer, where the average grain size increases as Hep concentration rises [7]. The more porous structure of the $\mathrm{PP}_{0.20 \mathrm{Hep}}$ film can offer a greater surface area and a better access for the molecule adsorption process than those of the $\mathrm{PP}_{0.40 \mathrm{Hep}}$ film.

\section{PPy films electrochemical characterization using EQCM}

In order to characterize the PPyxHep films electroactive behavior, $\mathrm{CV}$ technique was carried out in a Ringer solution, only for the rougher PРy $\mathrm{y}_{20 \mathrm{Hep}}$ film (Fig. 5). $\Delta \mathrm{f}$ was registered simultaneously as a function of potential. Both responses indicate that the conducting polymer can be reduced and oxidized without losing its electroactive behavior under repetitive cycling. Reduction and oxidation peaks, at -0.50 and at $-0.30 \mathrm{~V}\left(\mathrm{Ag} / \mathrm{AgCl} / \mathrm{KCl}\right.$ (sat)), are related to the $\mathrm{Na}^{+}$cation insertion and expulsion, respectively $[6,12,13]$. When the potential is scanned in the cathodic direction, there is a decrease in the $\Delta \mathrm{f}$ value, due to the $\mathrm{Na}^{+}$cation insertion $(2.74 \mu \mathrm{g})$. If the scan is reverted in the anodic direction, the $\mathrm{Na}^{+}$cation expulsion occurs $(1.20 \mu \mathrm{g})$, and the $\Delta \mathrm{f}$ value is increased. Thus, the exchanged $\mathrm{Na}^{+}$ cation net mass is $1.54 \mu \mathrm{g}$, in order to maintain the polymer electroneutrality. This value is approximately twice the value reported in the literature for the PPy film doped with simple anions $(\sim 0.70 \mu \mathrm{g})[14,15]$, and it is in concordance with the value reported by Zhou et al. [9].

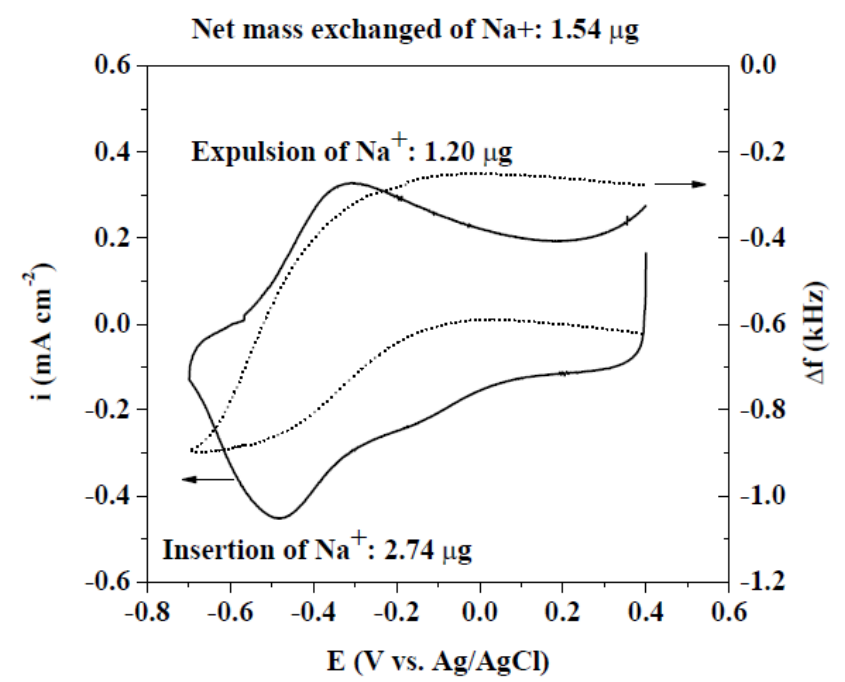

Figure 5. Redox behavior and EQCM response obtained for the PPy $\mathrm{y}_{0.20 \mathrm{Hep}}$ film in a Ringer solution. Potential range: -0.70 to $+0.40 \mathrm{~V}$. Scan rate: $0.01 \mathrm{~V} \mathrm{~s}^{-1}$. PPy $0.20 \mathrm{Hep}$ films were prepared at a current density of $0.624 \mathrm{~mA} \mathrm{~cm}^{-2}$, during $300 \mathrm{~s}$, in a $0.50 \mathrm{M} \mathrm{Py}$ solution with $0.20 \mathrm{~g} \mathrm{~L}^{-1}$ of Hep.

\section{Characterization of thrombin adsorption onto PPy films using EQCM}

The OCP vs. $t$ responses during thrombin adsorption onto PРy $\mathrm{xHep}_{\mathrm{x}}$ films were registered in a Ringer solution (Fig. 6). The initial OCP values correspond to the PPy $_{\mathrm{xHep}}$ films immersed in $2 \mathrm{~mL}$ of the Ringer solution without thrombin. After 
$90 \mathrm{~s}$ of immersion, $1 \mathrm{~mL}$ of the Ringer solution with $25 \mathrm{NIH}$ units or $20.15 \mu \mathrm{g}$ of thrombin was added. A potential spike was observed for all the PPyxHep films, as a consequence of the electrical double layer perturbation. After that, the OCP has a similar trend.

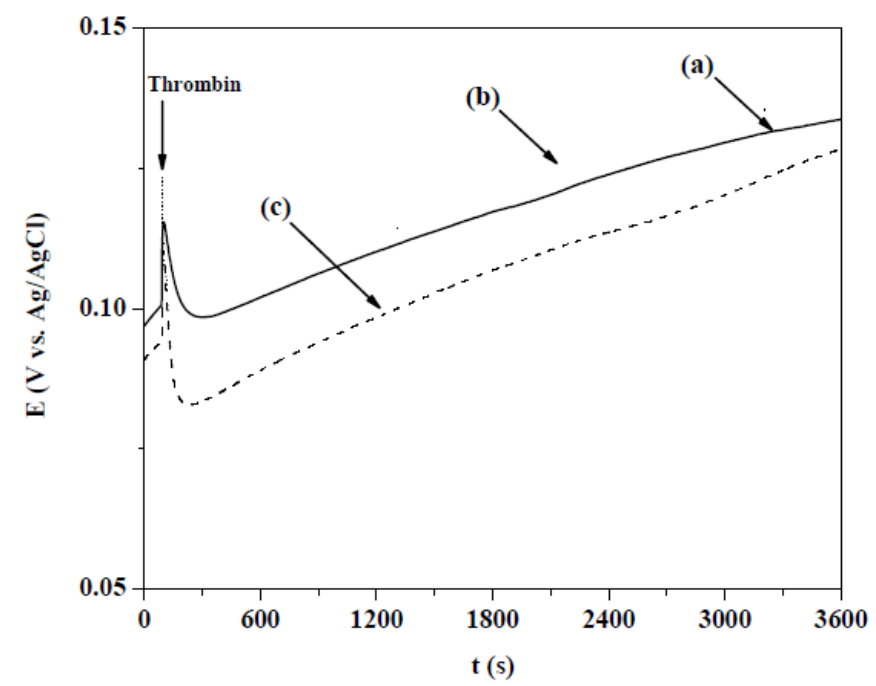

Figure 6. $O C P$ vs. $t$ responses to thrombin adsorption onto $\mathrm{PPy}_{\mathrm{xHep}}$ films in a Ringer solution. PPy $\mathrm{y}_{\mathrm{xHep}}$ films were prepared at a current density of $0.624 \mathrm{~mA} \mathrm{~cm}{ }^{-2}$, during $300 \mathrm{~s}$, in a $0.50 \mathrm{M}$ Py solution with: (a) 0.20 , (b) 0.30 and (c) $0.40 \mathrm{~g} \mathrm{~L}^{-1}$ of Hep. After $90 \mathrm{~s}$ of immersion, $1 \mathrm{~mL}$ of the Ringer solution with $25 \mathrm{NIH}$ units or $20.15 \mu \mathrm{g}$ of thrombin was added.

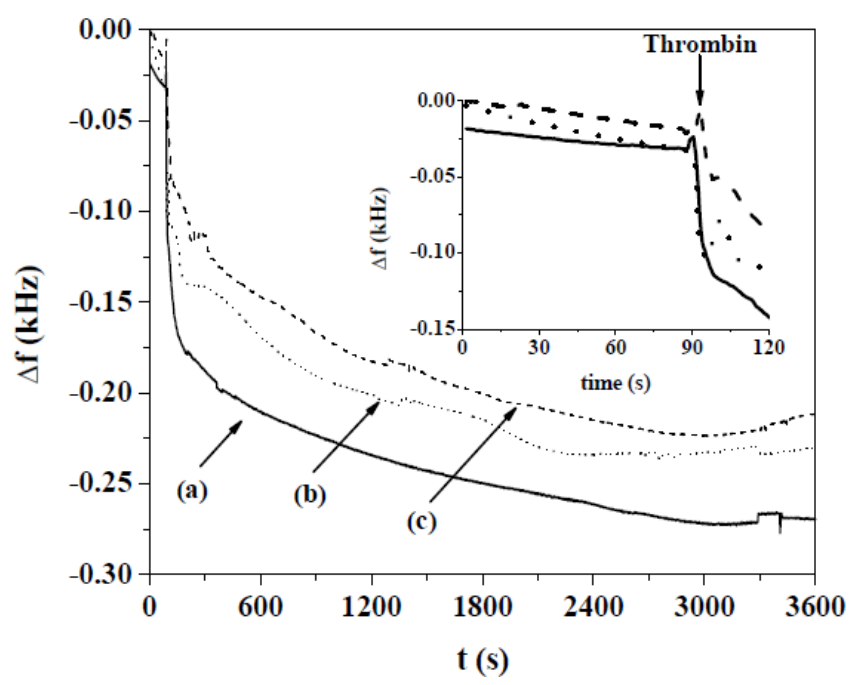

Figure 7. $\Delta f$ vs. $t$ responses to thrombin adsorption on $\mathrm{PP}_{\mathrm{xH}}$ films obtained at OCP condition in a Ringer solution. PPyxHep films were prepared at a current density of 0.624 $\mathrm{mA} \mathrm{cm}$, during $300 \mathrm{~s}$, in a $0.50 \mathrm{M}$ Py solution with: (a) 0.20 , (b) 0.30 and (c) $0.40 \mathrm{~g} \mathrm{~L}^{-1}$ of Hep. After $90 \mathrm{~s}$ of immersion, $1 \mathrm{~mL}$ of the Ringer solution with $25 \mathrm{NIH}$ units or 20.15 $\mu \mathrm{g}$ of thrombin was added.

The addition, to the PРy $\mathrm{x}_{\mathrm{xHep}}$ films, of the Ringer solution with thrombin (90 s) produced an abrupt decrease in the $\Delta \mathrm{f}$ values, due to thrombin adsorption onto their surfaces (Fig. 7). The highest thrombin adsorption associated with the maximum frequency shift in the negative direction was achieved for the lowest 
Hep concentration $\left(0.2 \mathrm{~g} \mathrm{~L}^{-1}\right)$. This response can be explained by considering that the $\mathrm{PP}_{0.20 \mathrm{Hep}}$ film had a greater surface area, according to the roughness value previously measured by AFM. $\Delta \mathrm{f}$ and $\Delta \mathrm{m}$ values associated with the adsorbed

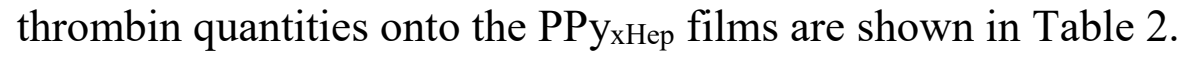

Table 2. $\Delta f$ and $\Delta m$ values obtained for thrombin adsorption onto PPyxHep films in a Ringer solution. $\mathrm{PPy}_{\mathrm{xHep}}$ films were formed on an $\mathrm{Au} / \mathrm{TiO}_{2}$ coated quartz crystal electrode, at a current density of $0.624 \mathrm{~mA} \mathrm{~cm}^{-2}$, during $300 \mathrm{~s}$, in a $0.50 \mathrm{M}$ Py solution with different Hep concentrations $\left(0.20,0.30\right.$ and $\left.0.40 \mathrm{~g} \mathrm{~L}^{-1}\right)$.

\begin{tabular}{|c|c|c|}
\hline PPy film & $\begin{array}{c}-\Delta f \\
(\mathrm{kHz})\end{array}$ & $\begin{array}{c}\Delta m \\
(\mu \mathrm{g})\end{array}$ \\
\hline $\mathrm{PP}_{0.20 \mathrm{Hep}}$ & 0.27 & 1.19 \\
\hline $\mathrm{PP}_{0.30 \mathrm{Hep}}$ & 0.23 & 1.02 \\
\hline $\mathrm{PP}_{0.40 \mathrm{Hep}}$ & 0.21 & 0.94 \\
\hline
\end{tabular}

The influence of the conducting polymer oxidation state on the thrombin adsorption process has been also analyzed. The PPy $0.20 \mathrm{Hep}$ film was pre-oxidized or pre-reduced by the application of a current pulse $\left( \pm 0.3 \mathrm{~mA} \mathrm{~cm}{ }^{-2}\right.$, during $\left.30 \mathrm{~s}\right)$ to a Ringer solution, and then the thrombin affinity was examined for both redox states of the conducting polymer (Fig. 8). Higher thrombin adsorption is achieved for the pre-oxidized form of the $\mathrm{PP}_{0.20 \mathrm{Hep}}$ film, in relation to the freshly prepared sample (Fig. 8, curve (b), in respect to curve (a)). On the other hand, thrombin showed a very low adsorption onto the $\mathrm{PP}_{0.20 \mathrm{Hep}}$ film pre-reduced form (Fig. 8, curve (c)). It is even observed, according to the increase in the $\Delta \mathrm{f}$ values, that thrombin desorption occurs from the pre-reduced PPy . $_{20 \mathrm{Hep}}$ film around 300 and $2100 \mathrm{~s}$.

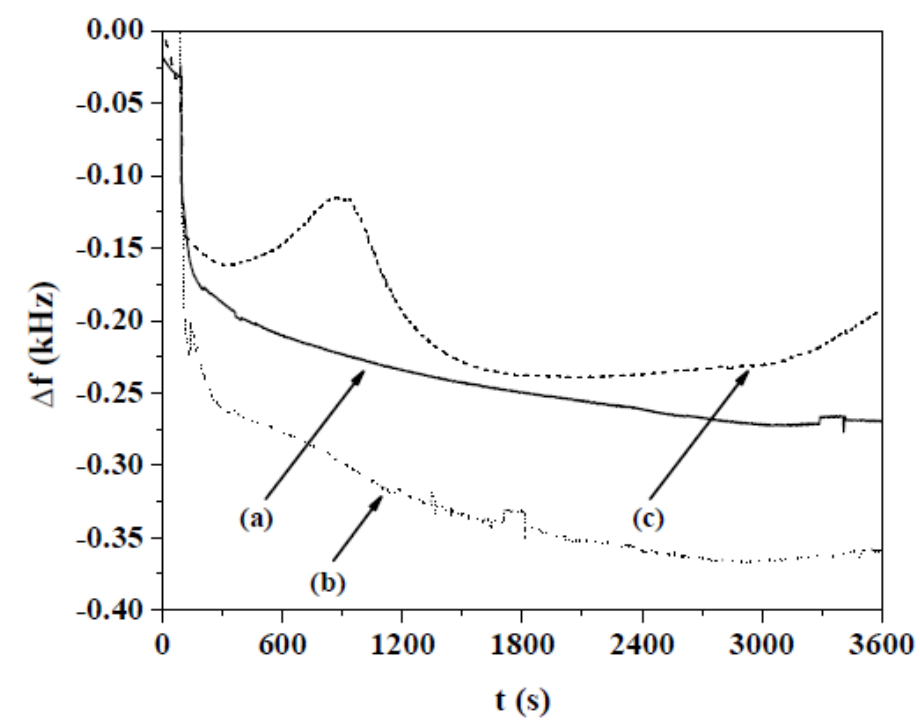

Figure 8. $\Delta f$ ss. $t$ responses to thrombin adsorption on the freshly prepared, pre-oxidized and pre-reduced forms of PPy.20Hep films, obtained at OCP condition, in a Ringer solution. After $90 \mathrm{~s}$ of immersion, $1 \mathrm{~mL}$ of the Ringer solution with $25 \mathrm{NIH}$ units or $20.15 \mu \mathrm{g}$ of thrombin was added. Thrombin adsorption was performed on: (a) freshly prepared PРУ . $_{20 \mathrm{Hep}}$ film, (b) pre-oxidized $\mathrm{PP}_{0.20 \mathrm{Hep}}$ film (at $0.3 \mathrm{~mA} \mathrm{~cm}^{-2}$, during $30 \mathrm{~s}$, in a Ringer solution) and (c) pre-reduced PPy . $_{20 \mathrm{Hep}}$ film (at $-0.3 \mathrm{~mA} \mathrm{~cm}{ }^{-2}$, during $30 \mathrm{~s}$ in a Ringer solution). The $\mathrm{PP}_{0.20 \mathrm{Hep}}$ film was previously prepared at a current density of $0.624 \mathrm{~mA} \mathrm{~cm}^{-2}$, during $300 \mathrm{~s}$, in a $0.50 \mathrm{M}$ Py solution with $0.20 \mathrm{~g} \mathrm{~L}^{-1}$ of Hep. 
$\Delta \mathrm{f}$ and $\Delta \mathrm{m}$ values associated with thrombin adsorption, as a function of the redox state of the PPy $y_{0.20 \mathrm{Hep}}$ film, are shown in Table 3. It is known that the $\mathrm{Na}^{+}$cation regulates the thrombin activity in vivo [16]. It may be considered that if the $\mathrm{Na}^{+}$ cations concentration in the polymer matrix is increased, as a consequence of their insertion during the reduction process, thrombin would act like a procoagulant protein. On the other hand, if the $\mathrm{Na}^{+}$cations concentration in the polymer matrix decreases, as a result of their expulsion during the oxidation process, thrombin would act like as an anticoagulant protein, being heparin its specific substrate. These last facts could be related to the higher relative thrombin adsorption observed onto the pre-oxidized Hep-doped PPy film, in comparison to that of the freshly prepared and pre-reduced samples.

Table 3. $\Delta f$ and $\Delta m$ values obtained for thrombin adsorption onto freshly prepared, preoxidized and pre-reduced forms of $\mathrm{PP}_{0.20 \mathrm{Hep}}$ films in a Ringer solution. The PPУ0.20Нер film was previously formed on an $\mathrm{Au} / \mathrm{TiO}_{2}$ coated quartz crystal electrode, at a current density of $0.624 \mathrm{~mA} \mathrm{~cm}^{-2}$, during $300 \mathrm{~s}$, in a $0.50 \mathrm{M}$ Py solution with $0.20 \mathrm{~g} \mathrm{~L}^{-1}$ of Hep.

\begin{tabular}{lcc}
\hline Sample & $-\boldsymbol{\Delta} \boldsymbol{f}(\mathbf{k H z})$ & $\Delta \boldsymbol{m}(\boldsymbol{\mu g})$ \\
\hline Freshly prepared $\mathrm{PP}_{0.20 \mathrm{Hep}}$ film & 0.27 & 1.19 \\
Pre-oxidized $\mathrm{PP}_{0.20 \mathrm{Hep}}$ film & 0.36 & 1.59 \\
Pre-reduced PPy $\mathrm{y}_{0.2 \mathrm{Hep}}$ film & 0.19 & 0.85 \\
\hline
\end{tabular}

\section{Conclusions}

PPy films can be electropolymerized on an $\mathrm{Au} / \mathrm{TiO}_{2}$ coated quartz crystal electrode from solutions with a monomer and different Hep concentrations.

It was demonstrated that the PPy films are electroactive and present cation exchange properties under oxidation or reduction conditions in a Ringer solution.

The EQCM experiments show that thrombin is adsorbed onto the PPy coating, due to the presence of Hep molecules retained into the polymer matrix. In addition, the augment in the surface area of the porous dendritic PPy film produces an increase in the quantity of adsorbed thrombin, even when the Hep concentration decreases. On the other hand, a higher thrombin affinity was obtained for a pre-oxidized PPy film, in comparison to that of a freshly prepared sample. On the contrary, a decreased affinity was observed in the case of the pre-reduced PPy film.

This kind of PPy coating can be used as an antithrombogenic film, given that the Hep molecule remains immobilized into the polymer matrix, and that it has a strong affinity with thrombin.

\section{Acknowledgements}

The financial support of the Secretaría de Ciencia y Técnica - UNS (PGI 24/M146), the Consejo Nacional de Investigaciones Cientificas y Técnicas (CONICET - PIP 112-20150 -100147) and the Agencia Nacional de Promoción Científica y Tecnológica (ANPCYT PICT-2015-0726) is gratefully acknowledged.

\section{References}

1. Muñoz EM Linhardt RJ. Heparin-Binding Domains in Vascular Biology. Arterioscler Thromb Vasc Biol. 2004;24:1549-1557. https://doi.org/10.1161/01.ATV.0000137189.22999.3f 
2. Seyrek E, Dubin P. Glycosaminoglycans as polyelectrolytes. Adv Colloid Interface Sci. 2010;158:119-129. https://doi.org/10.1016/j.cis.2010.03.001

3. Guimard NK, Gomez N, Schmidt CE. Conducting polymers in biomedical engineering. Prog Polym Sci. 2007;32:876-921. https://doi.org/10.1016/J.PROGPOLYMSCI.2007.05.012

4. Kaur G, Adhikari R, Cass P, et al. Electrically conductive polymers and composites for biomedical applications. RSC Adv. 2015;5:37553-37567. https://doi.org/10.1039/C5RA01851J

5. Hepel M. Composite polypyrrole films switchable between the anion- and cation-exchanger states. Electrochim Acta. 1996;41:63-76. https://doi.org/10.1016/0013-4686(95)00286-N

6. Hepel J, Bruckestein S, Hepel M. Effect of $\mathrm{pH}$ on Ion Dynamics in Composite PPy/Heparin Films. Microchem J. 1997;55:179-191. https://doi.org/10.1006/mchj.1996.1411

7. Flamini DO, Valle MI, Sandoval MJ, et al. Electrodeposition study of polypyrrole-heparin and polypyrrole-salicylate coatings on Nitinol. Mater Chem Phys. 2018;209:76-85. https://doi.org/10.1016/j.matchemphys.2018.01.065

8. Cornelius RM, Sanchez J, Olsson P, et al. Interactions of antithrombin and proteins in the plasma contact activation system with immobilized functional heparin. J Biomed Mater Res A. 2003;67:475-483. https://doi.org/10.1002/jbm.a.10118

9. Zhou D, Too CO, Wallace GG. Synthesis and characterisation of polypyrrole/heparin composites. React Funct Polym. 1999;39:19-26. https://doi.org/10.1016/S1381-5148(97)00149-1

10. Sauerbrey G. Verwendung von schwinquarzen zur wägung dünner schichten und zurmikrowägung. Zeitschrift für Physik. 1959;55:206-222. https://doi.org/10.1007/BF01337937

11. Bruckenstein S, Shay M. Experimental aspects of use of the quartz crystal microbalance in solution. Electrochim Acta. 1985;30:1295-1300. https://doi.org/10.1016/0013-4686(85)85005-2

12. John R, Wallace GG. Doping-dedoping of polypyrrole: a study using currentmeasuring and resistance-measuring techniques. $\mathrm{J}$ Electroanal Chem. 1993;354:145-160. https://doi.org/10.1016/0022-0728(93)80330-K

13. Cascalheira AC, Aeiyach S, Lacaze PC, et al. Electrochemical synthesis and redox behaviour of polypyrrole coatings on copper in salicylate aqueous solution. Electrochim Acta. 2003;48:2523-2529. https://doi.org/10.1016/S0013-4686(03)00295-0

14. Hodgson AJ, Gilmore K, Small C, et al. Reactive supramolecular assemblies of mucopolysaccharide, polypyrrole and protein as controllable biocomposites for a new generation of 'intelligent biomaterials'. Supramol Sci. 1994;1:77-83. https://doi.org/10.1016/0968-5677(94)90013-2

15. Shimidzu T, Ohtani A, Iyoda $\mathrm{T}$, et al. Charge-controllable polypyrrole/polyelectrolyte composite membranes : Part II. Effect of incorporated anion size on the electrochemical oxidation-reduction process. J 
Electroanal Chem. 1987;224:123-135. https://doi.org/10.1016/00220728(87)85088-X

16. Voet D, Voet JG. Biochemistry. 4th Edition. New York: John Wiley \& Sons Inc; 2011. 